\title{
Morpho-anatomical study of the cladodes of Homalocladium platycladum (F.J. Muell.) L.H. Bailey (Polygonaceae)
}

\author{
Jane M. Budel ${ }^{\text {*, Paulo V. Farago }}{ }^{2}$, Márcia do R. Duarte ${ }^{1}$, Inês J.M. Takeda ${ }^{3}$ \\ ${ }^{1}$ Departamento de Farmácia,Universidade Federal do Paraná, Av. Pref. Lothário Meissner, 632, 80210-170, \\ Curitiba, PR, Brasil, \\ ${ }^{2}$ Departamento de Ciências Farmacêuticas, Universidade Estadual de Ponta Grossa, Av. Carlos Cavalcanti, 4748, \\ 84030-900, Ponta Grossa, PR, Brasil, \\ ${ }^{3}$ Departamento de Tecnologia de Alimentos e Medicamentos, Universidade Estadual de Londrina, Caixa Postal \\ 6001, 86051-970, Londrina, PR, Brasil
}

\begin{abstract}
RESUMO: "Estudo morfoanatômico dos cladódios de Homalocladium platycladum (F.J. Muell.) L.H. Bailey (Polygonaceae)". Homalocladium platycladum, popularmente conhecido como fita-de-moça ou solitária, é um táxon pertencente à família Polygonaceae, tendo importância como espécie ornamental e medicinal, de acordo com a medicina tradicional oriental e brasileira. $\mathrm{O}$ objetivo do presente trabalho foi avaliar a morfoanatomia dos cladódios de H. platycladum. $\mathrm{O}$ material botânico foi fixado, seccionado e preparado segundo as técnicas habituais de microscopia fotônica e eletrônica de varredura. $O$ cladódio revelou células epidérmicas revestidas por cutícula espessada e estriada. A epiderme unisseriada apresentou estômatos paracíticos e tricomas glandulares localizados em pequenas depressões. Os tricomas foram descritos como capitados, com pedicelo curto e porção apical pluricelular. A região cortical do cladódio revelou faixas descontínuas de colênquima, alternadas com esclerênquima, também encontrado como faixa subjacente. Após a faixa esclerenquimática, limitando internamente o córtex, verificou-se a presença de uma bainha amilífera. O cilindro vascular foi constituído de feixes colaterais. A medula revelou a presença de células parenquimáticas e idioblastos contendo drusas de oxalato de cálcio.
\end{abstract}

Unitermos: Homalocladium platycladum, Polygonaceae, cladódio, morfoanatomia.

\begin{abstract}
Homalocladium platycladum is a Polygonaceae species, popularly known as fita-demoça or solitária that has been used as ornamental and medicinal plant, according to Oriental and Brazilian traditional medicine. The aim of this work was to evaluate the morpho-anatomy of the $H$. platycladum cladodes. The botanical material was fixed, sectioned and prepared according to usual light and scanning microtechniques. The cladode presented epidermal cells coated with thick and striate cuticle. The uniseriate epidermis showed paracytic stomata and glandular trichomes inserted in small depressions. These trichomes were capitate and presented short stalk and multicellular head. The cortex showed strands of chlorenchyma alternating with sclerenchyma that was an extension of a sclerenchymatic sheath. An internal boundary of the cortex was represented by a starch sheath. The vascular system consisted of collateral bundles and the pith showed parenchymatic cells and idioblasts containing calcium oxalate druses.
\end{abstract}

Keywords: Homalocladium platycladum, Polygonaceae, cladode, morpho-anatomy.

\section{INTRODUCTION}

The Polygonaceae family comprises approximately 40 genera and 800 species located in tropical, subtropical and temperate regions with tree, shrub, liana and predominately herb habit (Barroso, 1978; Cronquist, 1981; Joly, 1998). Morpho-anatomical aspects of Polygonaceae species were previously reported by Metcalfe and Chalk (1950), Inamdar (1969), Kapoort et al. (1971), Mitchell (1971), Esau (1974), Mauseth (1988), Fahn (1990), Lersten and Curtis (1992), Rocha and Rocha (1994), Rudall (1994) and Silva-Brambilla and Moscheta (2001).

In Polygonaceae, Antigonon guatemalense
Meissn., A. leptopum Hook. et Arn., Homalocladium platycladum (F.J. Muell.) L.H. Bailey, Muehlenbeckia complexa Meissn., Polygonum capitatum Buch-Ham. and $P$. orientale L. are used as ornamental plants (Lorenzi; Souza, 1999).

Nevertheless, medicinal and chemical studies have been conduced mainly in the Polygonum species (Mors et al., 2000; Cardoso et al., 2006). Polygonum spp. are popularly known as erva-de-bicho in Brazil, e.g., P. acre H.B.K, P. spectabile Mart., P. acuminatum H.B.K., P. hydropiper L. and P. hydropiperoides Michx. (Corrêa, 1974; 1984). These species are used internally as antihaemorrhoidal, astringent and antirheumatic (Martins et al., 1995; Mors et al., 2000) and as antiseptic for topical 
use (Gupta, 1995). Extracts of $P$. acre (synonym of $P$. punctatum Elliott) are employed as a topical haemostatic and in the treatment of internal hemorrhages (e.g., in uterus and hemorrhoids). The extracts of the aerial organs of $P$. hydropiper have demonstrated haemostatic action similar to $P$. acre, however with lower efficiency (Joachimovits, 1959). The leaf extract of $P$. stelligerum Cham. has showed the presence of rutin, particularly known for its antibacterial activity (Sartor, 1997). Jácome et al. (2004) reported the presence of triterpenes and/or steroids, coumarins, flavonoids, polyphenols, tannins and saponins in the aerial organs of $P$. hydropiperoides and $P$. spectabile. The study also showed variations on the polyphenol and tannin contents in samples of $P$. hydropiperoides collected in autumn and spring. In addition, it has been reported that $P$. multiflorum Thumb $\mathrm{MeOH}$ extracts inhibit the enzyme acetylcholinesterase (Barbosa-Filho et al., 2006a) and the angiotensin converting enzyme (Barbosa-Filho et al., 2006b).

$H$. platycladum is a one species in genus, native to the Solomon Islands and Papau New Guinea (Liberty Hyde Bailey Hortorium, 1976). This taxum is employed in Chinese traditional therapy (Ryu et al., 2001). In Malay herbal medicine, it is named jarilipan and externally applied to skin wounds caused by arthropods (Ong; Norzalina, 1999). In Brazil, it is popularly known as fita-de-moça or solitária (Lorenzi; Souza, 1999) and its indication is similar to Polygonum species. Although few studies have been carried out, mostly devoted to ecological aspects, Ryu et al. (2001) prepared an alcoholic extract of $H$. platycladum and screened its inhibitory activity against nitric oxide (NO) production in lipopolysaccharide (LPS)-activated macrophages. $H$. platycladum, as whole plant, showed $52 \%$ of inhibitory activity on the LPS-activated NO production in RAW 264.7 cells at $50 \mu \mathrm{g} . \mathrm{mL}^{-1}$. This inhibitor may be a useful candidate for the treatment of inflammatory diseases accompanied by the overproduction of NO.

The lack of available data about the morphology of $H$. platycladum has led to this investigation, which described the morpho-anatomy of the cladodes, contributing to the species identification for pharmacognostic purposes.

\section{MATERIAL AND METHODS}

The botanical material was collected from cultivated specimens in Umuarama, Paraná, Brasil (altitude: $475 \mathrm{~m}$, latitude: $23^{\circ} 47^{\prime} 57^{\prime \prime} \mathrm{S}$ and longitude: $53^{\circ}$ $18^{\prime} 50^{\prime \prime} \mathrm{W}$ ), in January 2005 . The species was identified by the voucher ICN 127138 stored at the herbarium from the Instituto de Ciências Naturais, at Universidade Federal do Rio Grande do Sul. Cladode fragments were fixed in FAA 70 (Johansen, 1940) and kept in 70\% ethanol solution (Berlyn; Miksche, 1976). Transverse and longitudinal freehand sections were stained either with toluidine blue (O'Brien et al., 1965) or astra blue and basic fuchsine
(Roeser, 1962). As additional data, the histochemical tests employed were: iodine-iodide to detect starch (Berlyn; Miksche, 1976), ferric chloride for phenolic compounds (Johansen, 1940), Sudan IV for lipophilic substances (Foster, 1949), hydrochloric phloroglucin for lignified elements (Sass, 1951) and sulphuric acid for calcium oxalate crystals (Oliveira et al., 1989). Photos were taken by Olympus BX40 light microscope attached to the control unit PM20. For scanning electron microscopy (SEM) analysis (Souza, 1998), cladodes fixed in FAA 70 were dehydrated in a graded ethanolic series and critical point dried in a Bal-Tec CPD-030, coated with gold in a Balzers SCD-030 and examined by Jeol JSM- 6360LV microscope.

\section{RESULTS}

H. platycladum is a perennial shrub, semiherbaceous, measuring up to $2 \mathrm{~m}$ height. Its stem is modified and forms plain, articulate, slightly striate and greenish cladodes (Figure 1) which have no leaves or bear reduced ones.

The cladode is flattened in transverse view (Figures 2 and 3) and exhibits uniseriate epidermis coated with a thick (Figure 6) and slightly striate cuticle (Figure 4). Paracytic stomata are encountered on the same level of surrounding epidermal cells and glandular trichomes are located in small epidermal depressions. These trichomes (Figures 5 and 6) are capitate and present a multicellular head, composed of 4 cells, and a short stalk.

The cortex has strands of chlorenchyma alternating with sclerenchyma (Figures 2 and 3). The latter is an extension of a sclerenchymatic sheath which is formed by 1 or 2 rows of fibers (Figures 2, 3 and 7). An internal boundary of the cortex is represented by a starch sheath, usually single-layered (Figures 2 and 7).

The vascular system (Figures 2, 3 and 7) consists of collateral bundles equidistantly distributed around the pith. This central region comprehends relatively large parenchymatic cells (Figures 2, 3 and 8), as comparing to the others cladode structures, and idioblasts containing druses of calcium oxalate (Figures 2 and 8).

\section{DISCUSSION}

H. platycladum differs from other species of Polygonaceae due to the modified caulinar structure which is constituted by cladodes. These cladodes are not leaves, but swollen water-storing and photosynthetic stem segments. The absence of other species in the Homalocladium genus avoid the morpho-anatomical discussion in this level, but may be compared with anatomical structures with similar functions for others taxa in the Poligonaceae family.

In general, Polygonaceae species have anomocytic stoma complex (Metcalfe; Chalk, 1950). Lersten and Curtis (1992), when analyzing the stomata 

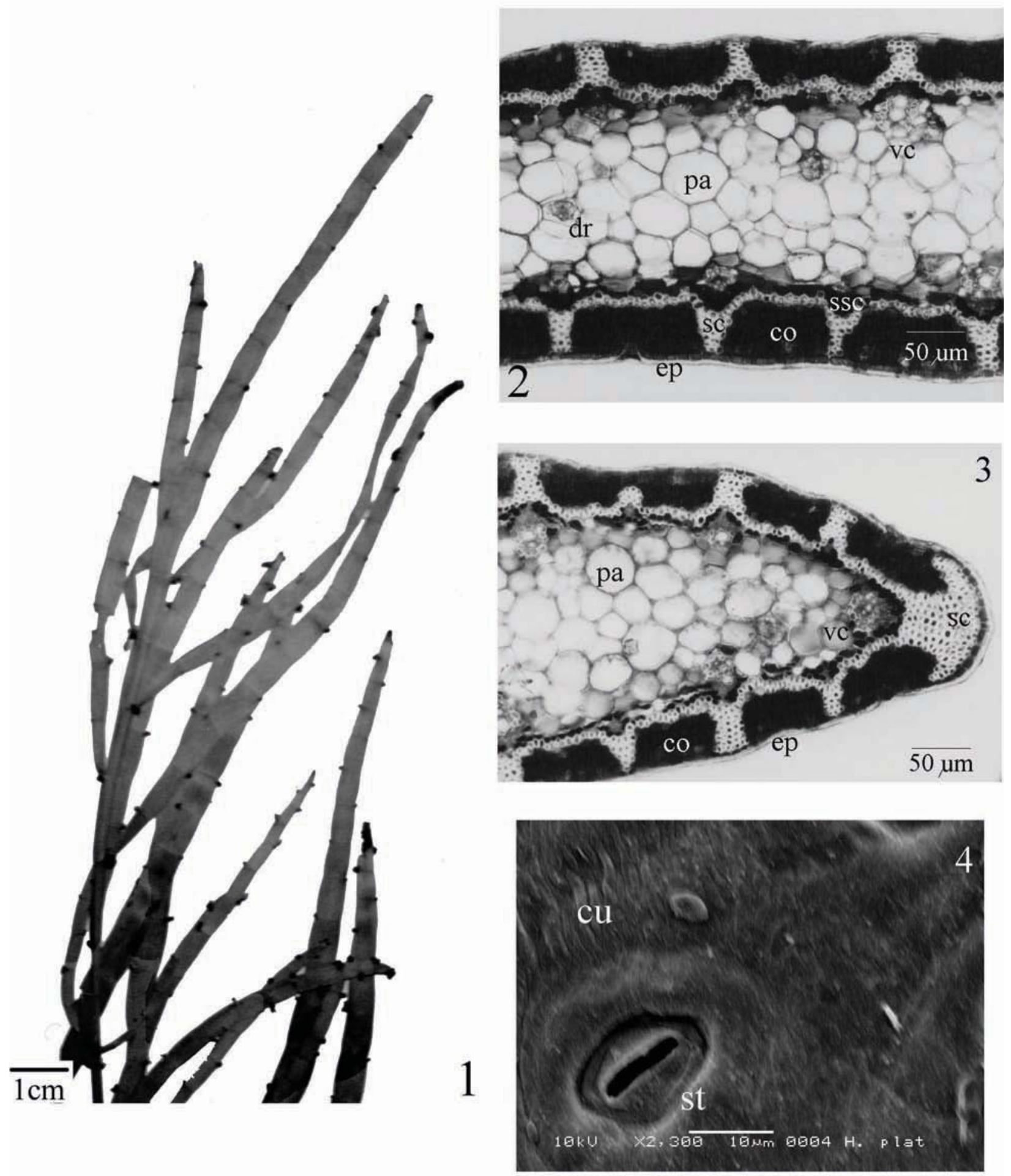

Figures 1-4. H. platycladum - 1. apical branches constituted by cladodes. 2-3. transections of the cladode in the medium and in the border, respectively. 4. Epidermis in the surface view (SEM). (co - chlorenchyma, cu - cuticle, $\mathrm{dr}$ - druse, ep - epidermis, pa - parenchyma, sc - sclerenchyma, ssc - starch sheath cells, st - stomatum, vc - vascular system).

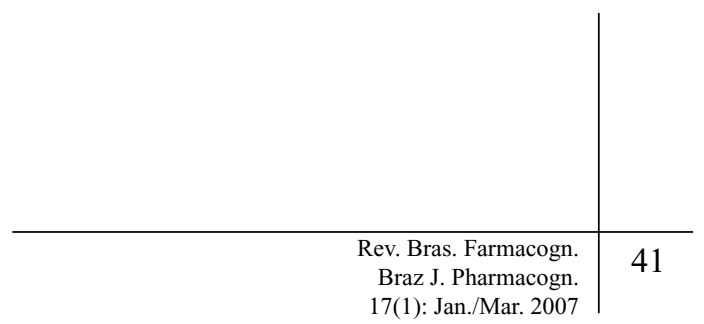



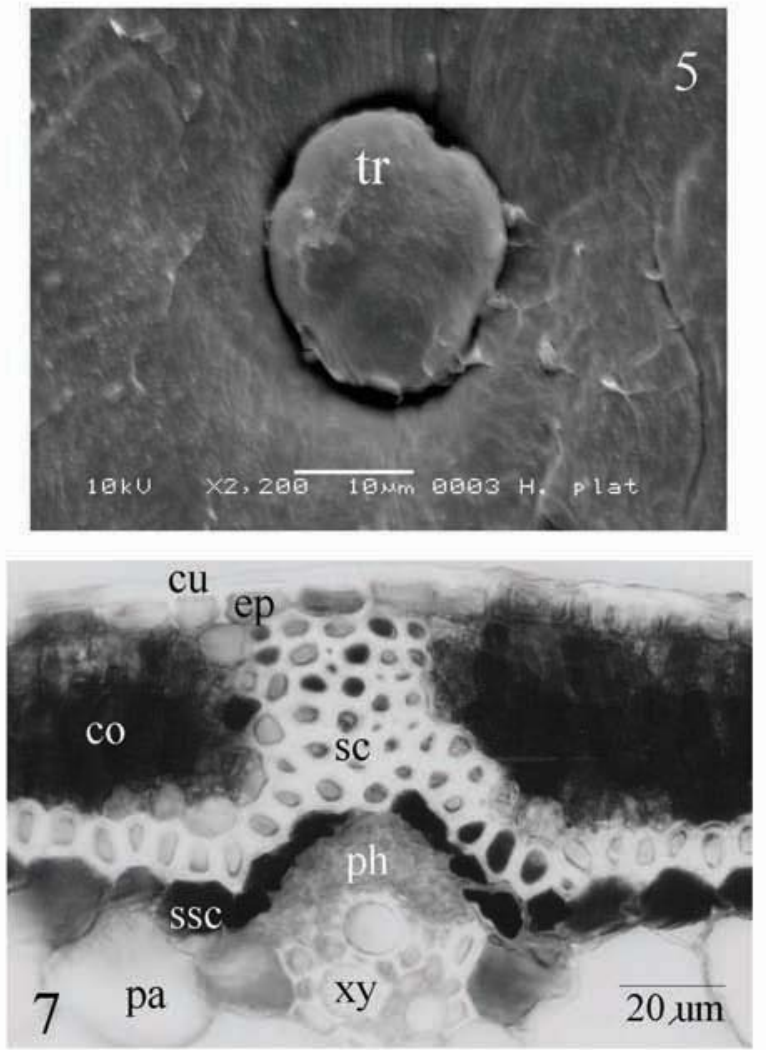
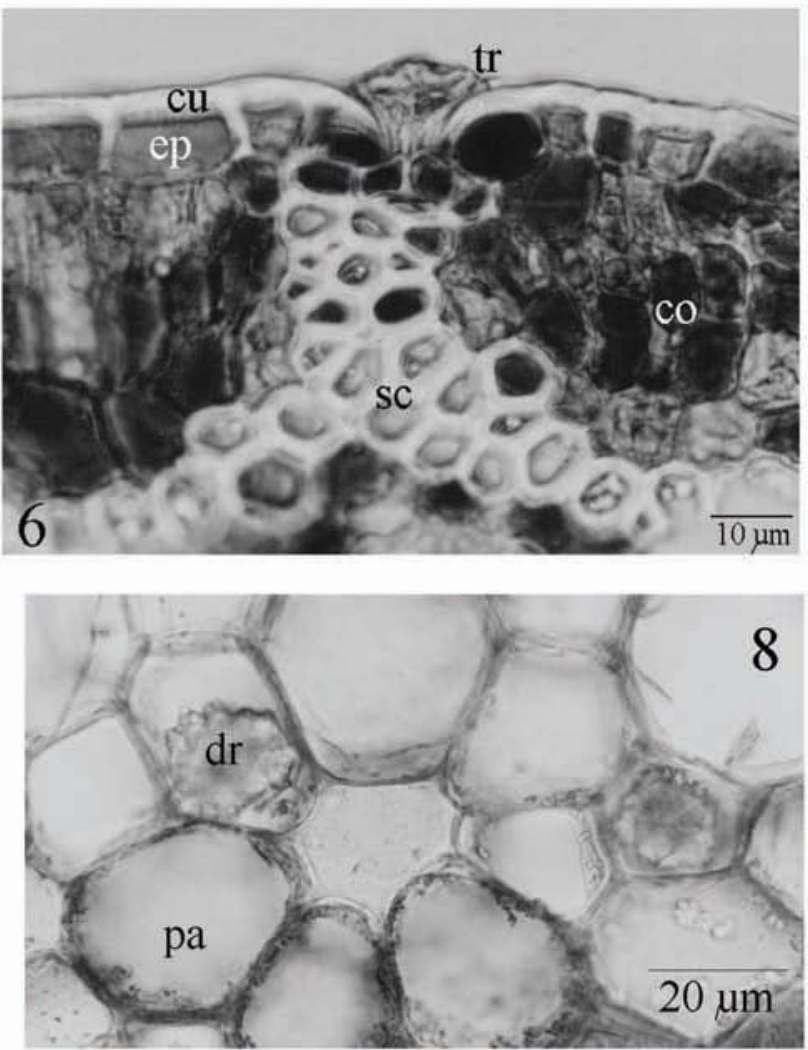

Figures 5-8. $H$. platycladum - 5. detail of the head of a glandular trichome inserted in an epidermal depression (SEM). 6. cladode transection, showing the epidermis and the cortex. 7. detail of the sclerenchyma and a collateral vascular bundle. 8. parenchymatic cells and idioblasts of the pith. (co - chlorenchyma, cu - cuticle, dr - druse, ep - epidermis, pa - parenchyma, ph - phloem, sc - sclerenchyma, ssc - starch sheath cells, tr - capitate trichome, xy - xylem).

in Polygonum, mentioned the absence of an anatomical pattern in the genus. Silva-Brambilla and Moscheta (2001) found a predominance of paracytic stomata in seven species of Polygonum. Nevertheless, in Ruprechtia laxiflora Meis. and Triplaris americana L., the same authors reported anomocytic stomata. In this study, $H$. platycladum shows paracytic stomata, contrasting with the usual findings in the family.

Lersten and Curtis (1992) stated that the glandular trichomes are often encountered in Magnoliopsida, also including the Polygonaceae. Several authors reported their presence in Polygonum (Inamdar, 1969; Kapoort et al., 1971; Mitchell, 1971; Rocha; Rocha, 1994). According to Silva-Brambilla and Moscheta (2001), glandular trichomes in Polygonum spp. have a head with 4 or 8 cells and are eventually inserted in epidermal depressions. In $H$. platycladum, similar glandular trichomes are seen, however only with a 4-celled head.

Stems of Magnoliopsida often present amyloplasts in the innermost layer of the cortex, recognized as a starch sheath (Esau, 1974; Rudall, 1994). This starch sheath was also evidencied in H. platycladum. Crystals of various forms and sizes have been reported in different groups of plants (Mauseth, 1988) and the calcium oxalate ones have been the most frequent (Fahn, 1990). Silva-Brambilla and Moscheta (2001) found calcium oxalate crystals in Polygonum, Ruprechtia and Triplaris. Accordingly, druses of calcium oxalate are observed in the pith of $H$. platycladum.

The aspects of stomata and trichomes described in this work correspond with other Polygonaceae leaves (Inamdar, 1969; Kapoort et al., 1971; Mitchell, 1971; Rocha; Rocha, 1994; Silva-Brambilla; Moscheta, 2001).

As a combined analysis, the presence of cladodes associated to their anatomical organization can be applied for the $H$. platycladum identification and quality control.

\section{ACKNOWLEDGMENTS}

The authors are thankful to Nelson Ivo Matzenbacher from the ICN/UFRGS for the species identification, and to the CME/UFPR for the scanning electron micrographs.

\section{REFERENCES}

Barbosa-Filho JM, Medeiros KCP, Diniz MFFM, Batista LM, Athayde-Filho PF, Silva MS, Cunha EVL, Almeida 
JRGS, Quintans-Júnior LJ 2006a. Natural products inhibitors of the enzyme acetylcholinesterase. Rev Bras Farmacogn 16: 258-285.

Barbosa-Filho JM, Martins VKM, Rabelo LA, Moura MD, Silva MS, Cunha EVL, Souza MFV, Almeida RN, Medeiros IA 2006b. Natural products inhibitors of the angiotensin converting enzyme (ACE). A review between 1980-2000. Rev Bras Farmacogn 16: 421446.

Barroso GM 1978. Sistemática de angiospermas do Brasil. São Paulo: Universidade de São Paulo. v. 1.

Berlyn GP, Miksche JP 1976. Botanical microtechnique and cytochemistry. Ames: Iowa State University.

Cardoso CAL, Honda NK, Dias ES 2006. Avaliação do perfil cromatográfico em espécies de Polygonum e amostras comercializadas como "erva-de-bicho". Rev Bras Farmacogn 16: 236-245.

Corrêa MP 1974. Dicionário de plantas úteis do Brasil. Rio de Janeiro: Ministério da Agricultura, v. 1

Corrêa MP 1984. Dicionário de plantas úteis do Brasil. Rio de Janeiro: Ministério da Agricultura, v. 3.

Cronquist A 1981. An integrated system of classification of flowering plants. New York: Columbia University.

Esau K 1974. Anatomia das plantas com sementes. São Paulo: E. Blücher.

Fahn A 1990. Plant anatomy. 4. ed. Oxford: Pergamon.

Foster AS 1949. Practical plant anatomy. $2^{\text {nd }}$ ed. Princeton: D. Van Nostrand.

Gupta MP 1995. 270 Plantas medicinais iberoamericanas. Santafé de Bogotá: Presencia.

Inamdar JA 1969. Epidermal structure and development of stomata in some Polygonaceae. Proc. Indian Acad. Sci. 72: 91-98.

Jácome RLRP, Lopes DES, Recio RA, Macedo JF, Oliveira AB 2004. Caracterização farmacognóstica de Polygonum hydropiperoides Michaux e P. spectabile (Mart.) (Polygonaceae). Rev. Bras. Farmacogn. 14: 21-27.

Joachimovits DA 1959. Estudo farmacológico da ação antihemorrágica do Polygonum acre H.B.K. Med Cir Farm 278: 216-234.

Johansen DA 1940. Plant microtechnique. New York: McGraw Hill Book.

Joly AB 1998. Botânica: introdução à taxonomia vegetal. São Paulo: Nacional.

Kapoort LS, Kapoort SL, Sharma PC, Kapoort LD 1971. Epidermal and venation studies in the Indian species of Polygonum Linn. (Polygonaceae). Bull Bot Surv Indian 13: 244-259.

Lersten NR, Curtis JD 1992. Foliar anatomy of Polygonum (Polygonaceae): survey of epidermal and selected internal structure. Plant Syst Evol 182: 71-106.

Liberty Hyde Bailey Hortorium (eds.) 1976. A concise dictionary of plants cultivated in the United States and Canada. New York: Macmillan, Hortus Third.

Lorenzi H, Souza HM 1999. Plantas ornamentais do Brasil. 2. ed. Nova Odessa: Plantarum.

Martins ER, Castro DM, Castellani DC, Dias JE 1995. Plantas medicinais. Viçosa: Universitária.

Mauseth JD 1988. Plant anatomy. Menlo Park: Benjamin/ Cummings.

Metcalfe CR, Chalk L 1950. Anatomy of dicotyledons: leaves, stem, and woods in relation to taxonomy with notes on economic uses. Oxford: Clarendon. v. 1.
Mitchell LRS 1971. Comparative leaf structure of aquatic Polygonum species. Am J Bot 58: 342-360.

Mors WB, Rizzini CT, Pereira NA 2000. Medicinal plants of Brazil. Algonac: Reference Publications.

O'Brien TP, Feder N, McCully ME 1965. Polychromatic staining of plant cell walls by toluidine blue. Protoplasma 59: 368-373.

Oliveira F, Akisue G, Akisue MK 1989. Farmacognosia. São Paulo: Atheneu.

Ong HC, Norzalina J 1999. Malay herbal medicine in Gemencheh, Negri Sembilan, Malaysia. Fitoterapia 70: 10-14.

Rocha JF, Rocha IB 1994. Anatomia foliar de Polygonum acuminatum H.B.K. (Polygonaceae). Bradea 6: 312319.

Roeser KR 1962. Die nadel der schwartzkiefer-massenprodukt und kunstwerk der natur. Mikrokosmos 61: 33-36.

Rudall P 1994. Anatomy of flowering plants: an introduction to structure and developement. 2. ed. Cambridge: Cambridge University.

Ryu JH, Ahn H, Lee HJ, Feng L, Qun WH, Han YN, Han BH 2001. Inhibitory activity of Chinese medicinal plants on nitric oxide synthesis in lipopolysaccharideactivated macrophages. J Appl Pharm 9: 183-187.

Sartor CFP 1997. Estímulo químico e avaliação da atividade antibacteriana e anticancerígena da espécie Poligonum stelligerum Cham. (Polygonaceae). Maringá. Dissertação de Mestrado - Universidade Estadual de Maringá.

Sass JE 1951. Botanical microtechnique. $2^{\text {nd }}$ ed. Ames: Iowa State College.

Silva-Brambilla MG, Moscheta IS 2001. Anatomia foliar de Polygonaceae (Angiospermae) da planície de inundação do alto rio Paraná. Acta Scientiarum 23: 571-585.

Souza W 1998. Técnicas básicas de microscopia eletrônica aplicadas às Ciências Biológicas. Rio de Janeiro: Sociedade Brasileira de Microscopia Eletrônica. 